\title{
Corrigendum
}

\section{Announcement of Revision}

In the manuscript entitled "Genetic Relationships Among Hirado azalea Cultivars and Their Putative Parents Inferred from Flavonoid 3', 5' Hydroxylase Gene Sequences", which was published in Hort J. 90(1), p. 114-121, an error was found in Table 1. The characteristics of 'Ōmurasaki' is incorrect. The corrected version of Table 1 is attached below.

Table 1. The samples used for sequencing and genotyping in this study.

\begin{tabular}{|c|c|c|c|c|}
\hline & & \multicolumn{2}{|c|}{ Anthocyanin composition ${ }^{y}$} & \\
\hline & & Dp derivatives $(-)$ & Dp derivatives $(+)$ & \\
\hline \multirow[t]{3}{*}{ Wild species } & Ser. Scabra & & $R$. ripense 1,2 & \multirow{8}{*}{$\begin{array}{l}\text { PCR amplification } \\
\text { and gene cloning }\end{array}$} \\
\hline & & & R. macrosepalum 1,2 & \\
\hline & & & R. yedoense var. poukhanese 1 & \\
\hline \multirow[t]{5}{*}{ Cultivars } & Ryūkyū azalea group & & R. $\times$ mucronatum 'Shiro-ryūkyū' & \\
\hline & Hirado azalea group & & 'Ademurasaki' & \\
\hline & & & 'Hirado-no-homare' & \\
\hline & & & 'Hakuhō’' & \\
\hline & & & 'Shiro-kujyaku' & \\
\hline \multirow[t]{2}{*}{ Wild species ${ }^{2}$} & Ser. Scabra & R. scabrum $1-8$ & $R$. ripense 3-13 & \multirow{14}{*}{ PCR amplification } \\
\hline & & & R. macrosepalum $3,4,5$ & \\
\hline \multirow[t]{12}{*}{ Cultivars } & Hirado azalea group & 'Hinomoto' & ‘Taihō’ & \\
\hline & & 'Raijin' & 'Hatsuyuki' & \\
\hline & & 'Heiwa-no-hikari' & & \\
\hline & & 'Hiōgi’' & & \\
\hline & & 'Kumo-no-ue' & & \\
\hline & & 'Shinshō’ & & \\
\hline & & 'Hinode' & & \\
\hline & & 'Banzairaku' & & \\
\hline & & 'Momoyama' & & \\
\hline & & 'Seibo' & & \\
\hline & & 'Saotome' & & \\
\hline & Ōkirishima group & & ‘Ōmurasaki' & \\
\hline
\end{tabular}

z These wild species did not have their pigment composition confirmed, except for R. scabrum 1, 2 .

${ }^{y}$ Hirado azalea and 'Shiro-ryūkyū' have been investigated (Meanchaipiboon et al., 2020). 